\title{
Modulation of Pulmonary Vascular Remodeling in Hypoxia: Role of 15-LOX- 2/15-HETE-MAPKs Pathway
}

\author{
Xiufeng Yu $u^{a, b}$ Tingting Lia,b Xia Liu ${ }^{a, b}$ Hao Yu ${ }^{a, b}$ Zhongfei Hao ${ }^{c}$ Yingli Chen ${ }^{d}$ \\ Chen Zhang ${ }^{a, b}$ Yumei Liu ${ }^{a, b}$ Qian Li ${ }^{b}$ Min Mao ${ }^{a, b}$ Daling Zhua,b \\ aDepartment of Biopharmaceutical Sciences, College of Pharmacy, Harbin Medical University \\ (Daqing), Daqing, ${ }^{b}$ Biopharmaceutical Key Laboratory of Heilongjiang Province, Harbin, 'Department \\ of Neurosurgery, Second Affiliated Hospital of Harbin Medical University, Harbin, ${ }^{\mathrm{d} C o l l e g e ~ o f ~ M e d i c a l ~}$ \\ Laboratory Science and Technology, Harbin Medical University (Daqing), Daqing, China
}

\section{Key Words}

Pulmonary hypertension; vascular remodeling • 15-hydrocyeiosatetraenoic acid • Mitogenactivated protein kinase

\begin{abstract}
Background: We have previously shown that 15-hydroxyeicosatetraenoic acid (15-HETE) plays a critical role in pulmonary hypertension $(\mathrm{PH})$-associated vascular remodeling. However, the signaling mechanisms remain unclear. The purpose of this study was to investigate the role of 15-lipoxygenase-2 (15-LO-2)/15-HETE-mitogen-activated protein kinases (MAPKs) pathway in hypoxia-induced pulmonary vascular remodeling and the underlying mechanisms. Methods: The arterial wall thickness was measured by hematoxylin and eosin $(\mathrm{HE})$ staining in distal pulmonary arteries isolated from normal and PAH patient-derived lungs. The protein expression of phosphorylated extracellular signal-regulated kinase ( $p$-ERK) and phosphorylated p38 mitogen-activated protein kinases ( $p$-p38MAPK) were measured by Western blot in the lungs of PAH patients and hypoxia-induced rats. The apoptosis of cultured rat pulmonary arterial smooth muscle cells (PASMCs) was determined by Terminal deoxynucleotidyl transferase dUTP nick end labeling (TUNEL) and Flow cytometry. The cell proliferation and cell cycle in PASMCs following hypoxia were analyzed by bromodeoxyuridine incorporation and flow cytometry, respectively. Results: Our results showed that the levels of $p$-ERK and $p$-p38MAPK were both drastically elevated in lungs from human patients and hypoxic rats. The HE staining revealed that the medial wall thickness was higher in patients with PAH than normal humans. In cultured PASMCs, Hypoxia stimulated the cell proliferation, the cell cycle progression, and subsequently promoted cell differentiation and cell migration leading to the suppressed cell apoptosis. Furthermore, MAPKs- induced cell proliferation and anti-apoptosis in PASMCs is15-LO-2/15HETE activation-dependent. Conclusion: Our study indicates that hypoxia-induced pulmonary vascular remodeling is associated with increased
\end{abstract}

Dr. Daling Zhu

KARGER 125 


\section{Cellular Physiology Cell Physiol Biochem 2015;35:2079-2097 \begin{tabular}{ll|l} 
and BOI: 10.1159/000374015 & $\begin{array}{l}\text { C 2015 S. Karger AG, Basel } \\
\text { www.karger.com/cpb }\end{array}$ \\
\hline
\end{tabular}}

levels of 15-LO-2 and 15-HETE. 15-LO-2/15-HETE stimulates the cell proliferation and antiapoptosis in PASMCs through phosphorylation of ERK and p38MAPK, which subsequently contributing to hypoxia-induced pulmonary vascular remodeling.

Copyright (C) 2015 S. Karger AG, Basel

\section{Introduction}

Pulmonary hypertension $(\mathrm{PH})$ is a refractory disease characterized by increased pulmonary vascular resistance (PVR), leading to increased right ventricular afterload, eventually progression to right heart failure and death [1-4]. Vasoconstriction, structural remodeling and thrombosis in situ have been shown as the main pathological characteristics in the development of PH [2]. Numerous evidences indicate that hypoxia, a well-known stimulus of $\mathrm{PH}$, induces pulmonary vascular remodeling via stimulating cell proliferation, particularly in the tunica media of smooth muscle cells [4-6].

The enhanced proliferation and suppressed normal apoptosis of vascular smooth muscle cells (VSMCs) are considering as the major reasons of medial hypertrophy, vascular remodeling [7]. Furthermore, VSMCs can undergo reversible phenotypical changes in response to chronic hypoxia, and retain the capacities of proliferation and migration as well as secretion of matrix proteins [8]. The above evidence suggests that, the unbalance between proliferation and apoptosis in VSMCs may contribute to structure-functional alterations of the pulmonary arteries and the development of PH.

Mitogen-activated protein kinase (MAPK) is a key enzyme that promotes cellular growth and proliferation through the phosphorylation and inactivation of pro-apoptotic proteins. There are three families of MAPKs that have been previously identified in various cell types including extracellular signal-regulated kinase (ERK), c-Jun N-terminal kinase (JNK) and p38 mitogen-activated protein kinases (p38MAPK) [9]. MAPKs can be activated by a variety of stimuli, such as mitogens, growth factors, hormones, oxidants and stress factors etc [10, 11]. In the MAPKs superfamily, increased activation of ERK is a key step in cell proliferation in response to growth factors, agonists, and hormones [12-14]. In contrast, p38MAPK has been found to be involved in apoptosis, endotoxic response, and osmotic stress [1518]. JNK/stress activated protein kinase (SAPK) is response to growth factors, cytokines, environmental stress, ultraviolet light, oxidative stress, and heat shock [19-23]. It has been shown that activation of JNK by 5-hydroxytryptamine results in the enhanced proliferation and migration of pulmonary arterial smooth muscle cells (PASMCs) [24]. Recent studies suggest that p38MAPK play a pivotal role in fibroblast proliferation, PASMCs mitosis and apoptosis as well as differentiation of s mesenchymal stem cells [25-27]. The evidence suggests that MAPKs contribute to the hypoxia-induced PAH-associated pulmonary vascular remodeling.

15-Hydroxyeicosatetr-aenoic acid (15-HETE), a metabolite of arachidonic acid catalyzed by 15-lipoxygenase (15-LO), is significantly increased in pulmonary arteries under hypoxia [28]. We have previously shown that 15-HETE mediated hypoxia-induced pulmonary vascular adventitia fibrosis, medial hypertrophy, inflammation, migration and angiogenesis of intimal endothelial cells $[7,25,29,30]$. However, the mechanisms in molecular level underlying the hypoxia-induced pulmonary vascular remodeling are not fully understood.

In this study, we sought to determine whether 15-LO-2/15-HETE mediated hypoxiainduced pulmonary vascular remodeling through stimulates MAPK pathway.

\section{Materials and Methods}

15-HETE and nordihydroguaiaretic acid (NDGA) were purchased from Cayman Chemical Company (Ann Arbor, USA). The Cycle TEST PLUS DNA Reagent Kit and the annexin V-FITC kit were obtained from BD Biosciences (Bedford, MA). Bromodeoxyuridine (BrdU) proliferation assay Kit was purchased from 
the corporation of Millipore (Billerica, MA). Antibodies against 15-LO-2, $\alpha$-actin, OPN, t-ERK, p-ERK, Cyclin A, Cyclin E, PCNA, were purchased from Santa Cruz Biotechnology Inc. (Santa Cruz, USA). Cyclin D1, t-p38, p-p38, p-JNK, t-JNK antibodies were obtained from Cell Signaling Technology (Beberly, MA). U0126, SB203580, Sp600125 were purchased from Sigma (Sigma, USA). The terminal deoxynucleotidyl transferasemediated dUTP nick end-labeling (TUNEL) cell apoptosis detection kit, Caspase-3 activity kit, and Caspase-9 activity kit were obtained from Beyotime Institute of Biotechnology (Haimen, China). All other reagents were from common commercial sources.

\section{Patients Selection}

Written informed consent was obtained from all subjects. The treatment evaluated for this study was approved by the Harbin Medical University Ethical Committee for Use of Human Samples between October 2012 and March 2014. Inclusion criteria comprised of a mean pulmonary arterial pressure (mPAP) $\geq 25 \mathrm{mmHg}$ and pulmonary capillary wedge pressure (PCWP) $\leq 15 \mathrm{mmHg}$ using the right heart catheterization (RHC) at rest. We excluded patients with (1) patients with congenital heart diseases and (2) patients with unstable condition. Finally, twenty patients were recruited, and all of them underwent RHC. Human lung specimens were obtained from lung transplantation (PAH) or from lobectomy or pneumonectomy for localized lung cancer (Control). The selected patients were all underwent pulmonary remodeling, samples from Group 3 are patients with pulmonary hypertension due to lung diseases and /or hypoxaemia, six were with chronic obstructive pulmonary disease (COPD), four were with interstitial lung disease and two were with alveolar hypoventilation disorders. None of the patients harbor germline mutations BMPR2, ALK1 or ENG PAH (Table 1). Fresh lung tissues was immediately placed in cold oxygenated Krebs solution (116 mM NaCl, 4.2 $\mathrm{mM} \mathrm{KCl}, 2.5 \mathrm{mM} \mathrm{CaCl}_{2}, 1.6 \mathrm{mM} \mathrm{NaH}_{2} \mathrm{PO}_{4}, 1.2 \mathrm{mM} \mathrm{MgSO}_{4}, 22 \mathrm{mM} \mathrm{NaHCO}_{3}$ and $11 \mathrm{mM}$ D-glucose with pH of

Table1. Demographic, clinical and hemodynamic variables of patients with PAH

\begin{tabular}{|c|c|}
\hline Characteristics & Value \\
\hline Age, $y$ & $43 \pm 8$ \\
\hline \multicolumn{2}{|l|}{ Gender } \\
\hline Male, n (\%) & $12(40 \%)$ \\
\hline Female, n (\%) & $16(60 \%)$ \\
\hline \multicolumn{2}{|l|}{ Diagnosis } \\
\hline 1.Idiopathic pulmonary arterial hypertension & $5(20 \%)$ \\
\hline 2. Familial pulmonary arterial hypertension & $3(20 \%)$ \\
\hline 3. pulmonary hypertension due to lung diseases and /or hypoxaemia & $12(60 \%)$ \\
\hline 3.1 chronic obstructive pulmonary disease (COPD) & 6 \\
\hline 3.2 interstitial lung disease & 4 \\
\hline 3.3 alveolar hypoventilation disorders. & 2 \\
\hline Body mass index, $\mathrm{kg} / \mathrm{m}^{2}$ & $20.66 \pm 1.8$ \\
\hline Heart rate, beats/min & $80 \pm 11$ \\
\hline \multicolumn{2}{|l|}{ Blood pressure, $\mathrm{mmHg}$} \\
\hline Systolic & $114 \pm 18$ \\
\hline Diastolic & $67 \pm 11$ \\
\hline \multicolumn{2}{|l|}{ WHO pulmonary hypertension function classes } \\
\hline $\mathrm{I} / \mathrm{II}, \mathrm{n}(\%)$ & $5(20 \%)$ \\
\hline III, n(\%) & $10(50 \%)$ \\
\hline IV, $\mathrm{n}(\%)$ & $5(30 \%)$ \\
\hline Mean right atrial pressure, $\mathrm{mmHg}$ & $7 \pm 5$ \\
\hline Mean pulmonary arterial pressure, $\mathrm{mmHg}$ & $56.81 \pm 13.33$ \\
\hline Pulmonary capillary wedge pressure, $\mathrm{mmHg}$ & $9 \pm 5$ \\
\hline Cardiac index, $\mathrm{L} / \mathrm{min} / \mathrm{m}^{2}$ & $2.29 \pm 1.08$ \\
\hline Pulmonary vascular resistance, dyn.s.cm ${ }^{-5}$ & $1068.5 \pm 309.4$ \\
\hline NT-pro brain natriuretic peptide, fmol/ml & $1215.4 \pm 715.7$ \\
\hline
\end{tabular}




\section{Cellular Physiology Cell Physiol Biochem 2015;35:2079-2097 \begin{tabular}{ll|l} 
and Biochemistry & $\begin{array}{l}\text { DOI: 10.1159/000374015 } \\
\text { Published online: April 07, } 2015\end{array}$ & $\begin{array}{l}\text { ○ 2015 S. Karger AG, Basel } \\
\text { www.karger.com/cpb }\end{array}$ \\
\hline
\end{tabular} Yu et al.: Role of MAPKs in Pulmonary Vascular Remodeling}

7.4). One of the fresh lung tissues was used for immunocytochemistry, and the rest of fresh lung tissues were used for pulmonary artery dissection. The distal pulmonary arteries were micro-dissected to achieve free of surrounding tissue under microscope. In the human samples the diameter range of pulmonary arterioles was $\leq 300 \mu \mathrm{m}$. This study was performed in compliance with the Declaration of Helsinki and was approved by the Institutional Review Board of the Second Affiliated Hospital of Harbin Medical University.

\section{Clinical and Hemodynamic Evaluation}

Hemodynamic parameters including mean right atrial pressure (mRAP), mPAP and PCWP were recorded in RHC examination. Pulmonary blood flow was measured by thermodilution method (the mean value of measurements at three time points). PVR was calculated as the following equation: PVR $=(\mathrm{mPAP}-$ PCWP)/Pulmonary blood flow.

\section{Animal use}

Animal care and use conformed to the Guide for the Care and Use of Laboratory Animals (NIH Publication 85-23, revised 1996). Adult male Wistar rats (150-180 g) were from the Experimental Animal Center of Harbin Medical University, which were approved by the Institutional Animal Care and Use Committee. This study was also approved by the ethics review board of Harbin Medical University ([2012]-006).

\section{Animals and lung tissues preparation}

Adult male rats were randomized to 9 days of normal and hypoxic environments with fractional inspired oxygen $\left(\mathrm{FiO}_{2}\right) 0.21$ and 0.12 , respectively, as previously described [28]. Normoxic rats were kept in the same room adjacent to the hypoxic chamber. To test the effects of nordihydroguaiaretic acid (NDGA), U0126, SB203580 and Sp600125 on hypoxia, rats were given NDGA $(650 \mathrm{mg} / \mathrm{kg}$ body weight (b.w.), orally, once daily) [7], U0126 (15 mg/kg b.w., orally, once daily), SB203580 (15 mg/kg b.w. orally, once daily), Sp600125 (10 mg/kg b.w., orally, oncedaily) since 2 days before hypoxia until they were used for experiment ( 9 days after hypoxia). At the end of the 9 days exposure period, right ventricular systolic pressure (RVSP) was measured by right heart catheterization, according to Song Y [31]. Then the heart and lungs were removed after euthanized. The lung tissues were used for a morphology section and the harvest of pulmonary arteries.

\section{The Hemodynamic Evaluation of hypoxia - model}

A 1.2 French Pressure Catheter (Scisense Inc.) was connected to the Scisense FA-404 recorder. When the right jugular vein was exposed, the catheter was inserted into the vein, then advanced into superior vena cava, and finally into right ventricular. RVSP was continuously recorded for 45 minutes. After measurement of RVSP the thorax was opened and the heart was dissected and weighed for calculation of the right ventricular hypertrophy index (ratio of right ventricular free wall weight over sum of septum plus left ventricular free wall weight: $(\mathrm{RV} / \mathrm{LV}+\mathrm{S})$.

\section{Cell culture}

The primary culture of rat pulmonary artery smooth muscle cells (PASMCs) was prepared according to our previously publication [32]. The purity of PASMCs was determined with specific monoclonal antibodies against smooth muscle $\alpha$-SMA. The cells were cultured in DMEM (Dulbecco's modified eagle's medium), contained 20\%-fetal bovine serum, 1\% penicillin and streptomycin. Passages 2-3 were used for the further experiments. Before experiment, the PASMCs were starvation for $24 \mathrm{~h}$ in the DMEM medium without serum. Then treated with siRNA plus 15-HETE (1 $\mu \mathrm{mol} / \mathrm{L})$ [29] in 5\% FBS-DMEM, or were exposed to hypoxia (92\% $\mathrm{N}_{2}-5 \% \mathrm{CO}_{2}-3 \% \mathrm{O}_{2}$ ) in the absence or presence of U0126 ( $\left.5 \mu \mathrm{mol} / \mathrm{L}\right), \mathrm{SB} 203580(5 \mu \mathrm{mol} / \mathrm{L})$.

\section{Morphometric Analysis}

The lung tissues were sliced into tissue blocks, and immersed in $4 \%$ paraformaldehyde for overnight fixation. Then fixed tissues were dehydrated, cleared, and embedded in paraffin base. The paraffin blocks were cut into sections of $5 \mu \mathrm{m}$ thick. Some sections were stained with hematoxylin and eosin. The total area in the vascular walls was quantified with high-resolution images of individual vessels that were analyzed using a color-recognition algorithm in the software of Image Pro Plus 6.0. 


\section{Cellular Physiology Cell Physiol Biochem 2015;35:2079-2097 \begin{tabular}{ll|l} 
and Biochemistry & $\begin{array}{l}\text { DOI: 10.1159/000374015 } \\
\text { Published online: April 07, } 2015\end{array}$ & $\begin{array}{l}\text { ○ 2015 S. Karger AG, Basel } \\
\text { www.karger.com/cpb }\end{array}$ \\
\hline
\end{tabular} Yu et al.: Role of MAPKs in Pulmonary Vascular Remodeling}

siRNA Design and Transfections

To silence the expression of 15-LO-2 gene, PASMCs were transfected with small interfering RNA, which was designed and synthesized by Bioneer. Non-targeted control siRNA (siNC) was used as negative control. The sense sequence of siRNA against 15-LO-2 and non-targeted control sequence were listed below: 15-LO-2 (GenBank accession no. NM 153301): sense, 5'-GACCCUAUUAUACCAGAGU dTdT-3', antisense, 5'-ACUCUGGUAUAAUAGGGUC dTdT-3'. siNC: sense, 5'-UUCUCCGAACGUGUCACGU dTdT-3', antisense, 5'-ACGUGACACGUUCGGAGAA dTdT-3'. Briefly, the PASMCs were cultured till 30\% - 50\% confluence and then $2 \mu \mathrm{g}$ siRNA and $10 \mu \mathrm{l}$ X-tremeGene siRNA Transfection Reagent were respectively diluted in serum-free Opti-MEM-1 medium for 5 min, then mixed together (siRNA/Transfection Reagent) at room temperature for another $20 \mathrm{~min}$ before added onto cells. After transfections, cells were quiesced for $24 \mathrm{~h}$ and used as required.

\section{MTT assay}

Cell viability was determined by the 3-(4, 5dimethylthiazol-2-yl)-2, 5 diphenyltetrazolium bromide (MTT) assay as described previously [29]. PASMCs were cultured in 96-well culture clusters (about $1 \times 10^{4}$

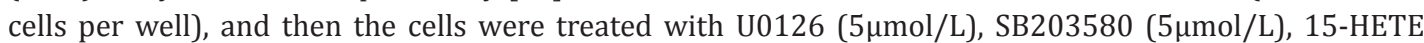
$(1 \mu \mathrm{mol} / \mathrm{L}), 15$-HETE Plus U0126, 15-HETE Plus SB203580, ethanol (vehicle) in DMEM with 5\% FBS, respectively. Then the samples were exposed to hypoxia $\left(3 \% \mathrm{O}_{2}\right)$. Ethanol and other agents at the indicated concentrations were added every $24 \mathrm{~h}$. After incubation in $37^{\circ} \mathrm{C}$ for $24 \mathrm{~h}$, the cells were treated with $0.5 \%$ MTT for another $4 \mathrm{~h}$. Amount of blue formazan dye formed from MTT is proportional to the number of survival cells. The reaction was terminated by adding DMSO (dimethyl sulfoxide) to the medium. The spectrophotometer absorbance at $540 \mathrm{~nm}$ was measured.

\section{Bromodeoxyuridine incorporation}

PASMCs were plated at $1 \times 10^{4}$ cells/well in 96-well plates, and then subjected to growth arrest for 24 $\mathrm{h}$ before exposed to hypoxia or treated with different agents in 5\% FBS DMEM. BrdU incorporation was measured by using BrdU proliferation assay kits according to the manufacturer's protocol. Briefly, the cells were labeled with $10 \mathrm{ng} / \mathrm{ml}$ of BrdU during the incubation, washed 3 times with cold Wash Buffer, fixed, airdried and incubated $1 \mathrm{~h}$ at room temperature with mouse anti-BrdU monoclonal antibody (diluted 1:200). The antibody was aspirated. The cells were washed 3 times and then incubated with peroxidase-conjugate goat anti-mouse IgG (1:2000) at room temperature for $30 \mathrm{~min}$. The cells were washed 3 times, and 100 $\mu \mathrm{l}$ substrates were added to each well and incubated for $30 \mathrm{~min}$ in darkness. Finally, positive stains were determined at the absorbance at dual-wave lengths of 450 and $540 \mathrm{~nm}$.

\section{Cell cycle and DNA analysis}

The Cycle TEST PLUS DNA Reagent Kit was used for examining whether the cell cycle was influenced by hypoxia or MAPK. We analyzed the proportion of cells in $G_{0} / G_{1}, S$ and $G_{2} / M$ phases by flow cytometry, as reported recently [29]. After exposure to drugs or hypoxia, the cells were treated by trypsin, then centrifuged and suspended with $1 \mathrm{ml}$ of cold PBS. Following twice washes with PBS, the cells were resuspended and fixed using 70\% ethanol. The ethanol was then removed and the cells were incubated in $200 \mu$ PBS. The cells were stained with propidium iodide according to the kit protocol. DNA fluorescence was measured and flow cytometry proceeding using BD FACS Calibur Flow Cytometer (Bedford, MA). For each sample, $2 \times 10^{4}$ events were accumulated in a histogram. The proportions of cells in the different phases of the cell cycle were calculated from each histogram.

\section{Immunofluorescence study and microscopic observation}

PASMCs were cultured on a poly-L-lysine-coated cover glass (15 $\mathrm{mm}$ diameter) and washed three times with PBS, followed by fixation with $4 \%$ paraformaldehyde at room temperature for $15 \mathrm{~min}$. After permeabilization with $0.01 \%$ Triton X-100 for $10 \mathrm{~min}$, the cells were blocked with $3 \%$ normal bovine serum at $37{ }^{\circ} \mathrm{C}$ for $30 \mathrm{~min}$, followed by incubation with anti- $\alpha$-SMA, anti-OPN antibodies (each concentration is 1:500, 1:200)in PBS at $4{ }^{\circ} \mathrm{C}$ overnight. After three washes with PBS, the cells were incubated with FITCconjugated secondary antibodies (1:100) and Cyc3-conjugated secondary antibodies (1:1000) diluted with PBS at $37^{\circ} \mathrm{C}$ for $2 \mathrm{~h}$. After mounted by cover glass, images were acquired by confocal laser scanning microscope (CLSM). 


\section{Cellular Physiology Cell Physiol Biochem 2015;35:2079-2097 \begin{tabular}{l|l} 
and Bioch 10.1159/000374015 & $\begin{array}{l}\text { C 2015 S. Karger AG, Basel } \\
\text { www.karger.com/cpb }\end{array}$ \\
\hline
\end{tabular}}

Yu et al.: Role of MAPKs in Pulmonary Vascular Remodeling

Migration Assays

For scratch-wounding cell migration assay, the PASMCs cultured in 6-well plates were wounded by pipette tips, given rise to one acellular 1-mm-wide lane per well, and the ablated cells were washed out with PBS. After that, cells were treated with vehicle or chemicals of interest in 5\% FBS DMEM. Migration was calculated based on the samewounded areas at time zero and $24 \mathrm{~h}$.

Flow cytometry

Annexin V-PE, 7-AAD kit was used to measure the percentage of apoptosis in accordance with the manufacturer's protocols (BD Biosciences). Briefly, after treatments, cells $\left(1 \times 10^{5}\right)$ were collected and resuspended in $100 \mathrm{ml}$ of binding buffer containing annexin V-PE and 7-AAD, then incubated for $15 \mathrm{~min}$ in the dark at room temperature, and the percentage of apoptotic cells was immediately assessed using a flow-cytometer.

TUNEL

Labeling 3'-end of fragmented DNA of apoptotic cells by TdT-UTP nick end labeling (TUNEL) method was performed in PASMCs. The cells cultured in a 6-well plate were treated as mentioned above, fixed with $4 \%$ paraformaldehyde phosphate buffer saline, rinsed with PBS, and then permeabilized by $0.1 \%$ TritonX-100 for $2 \mathrm{~min}$ on ice followed by TUNEL for $1 \mathrm{~h}$ at $37^{\circ} \mathrm{C}$. The FITC-labeled TUNEL-positive cells were imaged under a fluorescent microscopy at $488 \mathrm{~nm}$ excitation and $530 \mathrm{~nm}$ emission. The cells with green fluorescence were defined as apoptotic cells.

\section{Nuclear morphology determination}

Quantitative nuclear chromatin morphology was employed for the apoptosis counting. PASMCs were cultured in six-well culture cluster to- $60 \%$ confluency. The cells were treated as indicated groups. Then the cells were stained with $500 \mu \mathrm{l}$ of Hoechst (Beyotime) and incubated for $10 \mathrm{~min}$ at room temperature $\left(22-24^{\circ} \mathrm{C}\right)$. Stained cells were washed three times with PBS and imaged under a fluorescent microscope at $488 \mathrm{~nm}$ excitation and $405 \mathrm{~nm}$ emission. Cells with nuclear crenation, nuclear condensation and nuclear fractionation were defined as apoptotic cells.

\section{Measurement of caspase activity}

Caspase activities were detected by cleavages of Ac-DEVD-pNA (acetyl-Asp-Glu-Val-Aspp-nitroanilide), a caspase- 3 substrate, and AC-LEHD- $p$ NA (acetyl-Leu-Glu-His-Asp p-nitroanilide), a caspase- 9 substrate, according to the protocols provided by the manufacture. The specific caspase- 3 and caspase- 9 activities were normalized to the total protein and then expressed as fold changes of caspase- 3 and caspase- 9 activities compared with control cells (cultured in DMEM with10\% FBS).

\section{Measurement of 15-HETE levels}

To examine the generation of endogenous 15-HETE in PAs, the 15-HETE ELSIA kit (Catalog No.534721, Cayman) was performed for the detection of the amount of 15-HETE. Pulmonary arteries (PAs) were prepared homogenates by sonication, and ground with mortar and pestle and 0.1M/L Tris-HCL, PH7.4 and with $1 \mathrm{X} 10^{-3} \mathrm{M} / \mathrm{L}$ EDTA and $10^{-5} \mathrm{M} / \mathrm{L}$ indomethacin on ice. Then the amount of endogenous 15-HETE was measured by 15-HETE ELSIA Kit. The concentrations were calculated by Cayman Chemical Company Enzyme Immunoassay (ELSIA) Tools.

\section{Western blot Analysis}

The protein samples were extracted from PASMCs cells with the procedures essentially the same as described in details previously [7]. Protein samples $(20 \sim 50 \mu \mathrm{g})$ were fractionated by SDS-PAGE $(7.5-10 \%$ polyacrylamide gels). The primary antibodies against p-ERK (1:200), t-ERK (1:400), p-p38 (1:200), t-p-38 (1:400), p-JNK (1:200), t-JNK (1:400), 15-LO-2(1:500), $\alpha$-SMA (1:2000), $\beta$-actin (1:2000), GAPDH (1:2000), CyclinA (1:500), CyclinD1 (1:1000), CyclinE (1:100), PCNA (1:500), were used, with $\beta$-actin and GAPDH as an internal control.

\section{Statistics}

The composite data are expressed as means \pm SEM. Statistical analysis was performed with oneway ANOVA followed by Dunnett's test where appropriate. P valves $<0.05$ were considered statistically significant. 
\begin{tabular}{cl|l} 
Cellular Physiology & Cell Physiol Biochem 2015;35:2079-2097 \\
\cline { 2 - 2 } & $\begin{array}{c}\text { DOI: 10.1159/000374015 } \\
\text { and Biochemistry }\end{array}$ & $\begin{array}{l}\text { Published online: April 07, 2015 } \\
\text { www.karger.com/cpb }\end{array}$ \\
\cline { 2 - 3 } Yu et al.: Role of MAPKs in Pulmonary Vascular Remodeling &
\end{tabular}

\section{Results}

Morphology and hemodynamic changes of (pulmonary hypertension)PH patients and the expression of MAPKs in human PH

In order to test whether pulmonary vessels underwent remodeling in (pulmonary hypertension) PH patients, we used hematoxylin-eosin to detect the morphology of pulmonary vessels. Wall thickening was found in medium-sized pulmonary arteries obtained from lung tissues of human PH compared to normotensive lung samples (Fig. 1A). Demographics, clinical and hemodynamic data of enrolled PH patients were shown in Table 1. The pulmonary artery pressure (mPAP) was $55.81 \pm 13.33 \mathrm{mmHg}$ (Fig. 1B), and peripheral vascular resistance (PVR) was $1066.5 \pm 319.4$ dyn.s.cm ${ }^{-5}$ (Fig. 1C) in PH patients. We observed

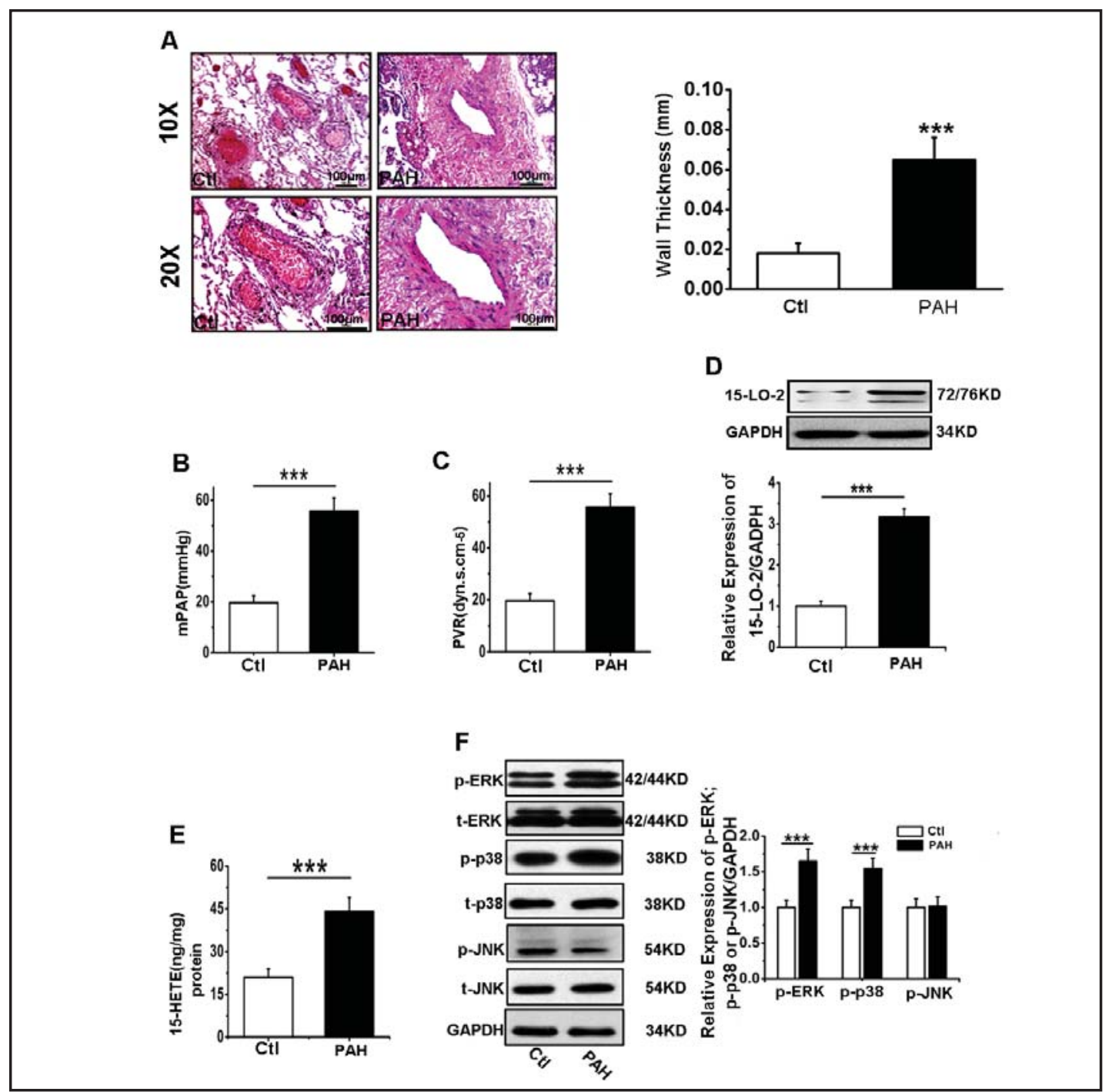

Fig. 1. A: The morphology analysis of pulmonary arterial was examined with H\&E stain. The results showed that the medial wall thickness was higher in human PH patients compared with that of normal hu$\operatorname{man}\left({ }^{* *} P<0.01 ; n=5\right)$. B: The RVSP data showed that the RVSP in patient with PH was increased ${ }^{* * *} P<0.001$; $n=5)$. C: Summarized data showed that the PVR was enhanced in patient with PH $(* * *<<0.001 ; n=5)$. D: The protein expression of 15-LO-2 in human pulmonary vessels $(* * * P<0.001 ; \mathrm{n}=5)$. E: The endogenous level of 15 -HETE measured by 15 -HETE EIA kit in human $\left({ }^{* * *} P<0.001 ; n=5\right)$. F: The expression of MAPK was detected pulmonary vessels in human $\mathrm{PH}$ at protein level ${ }^{* * *} P<0.001 \mathrm{vs}$ normal human $\left.\mathrm{n}=5\right)$. Bars are presented as mean \pm SEM."Ctl” means control; "PH" means pulmonary hypertension. 


\section{Cellular Physiology Cell Physiol Biochem 2015;35:2079-2097 \begin{tabular}{l|l}
\hline DOI: 10.1159/000374015 & (0) 2015 S. Karger AG, Basel
\end{tabular} and Biochemistry Published online: April 07, $2015 \quad$ www.karger.com/cpb}

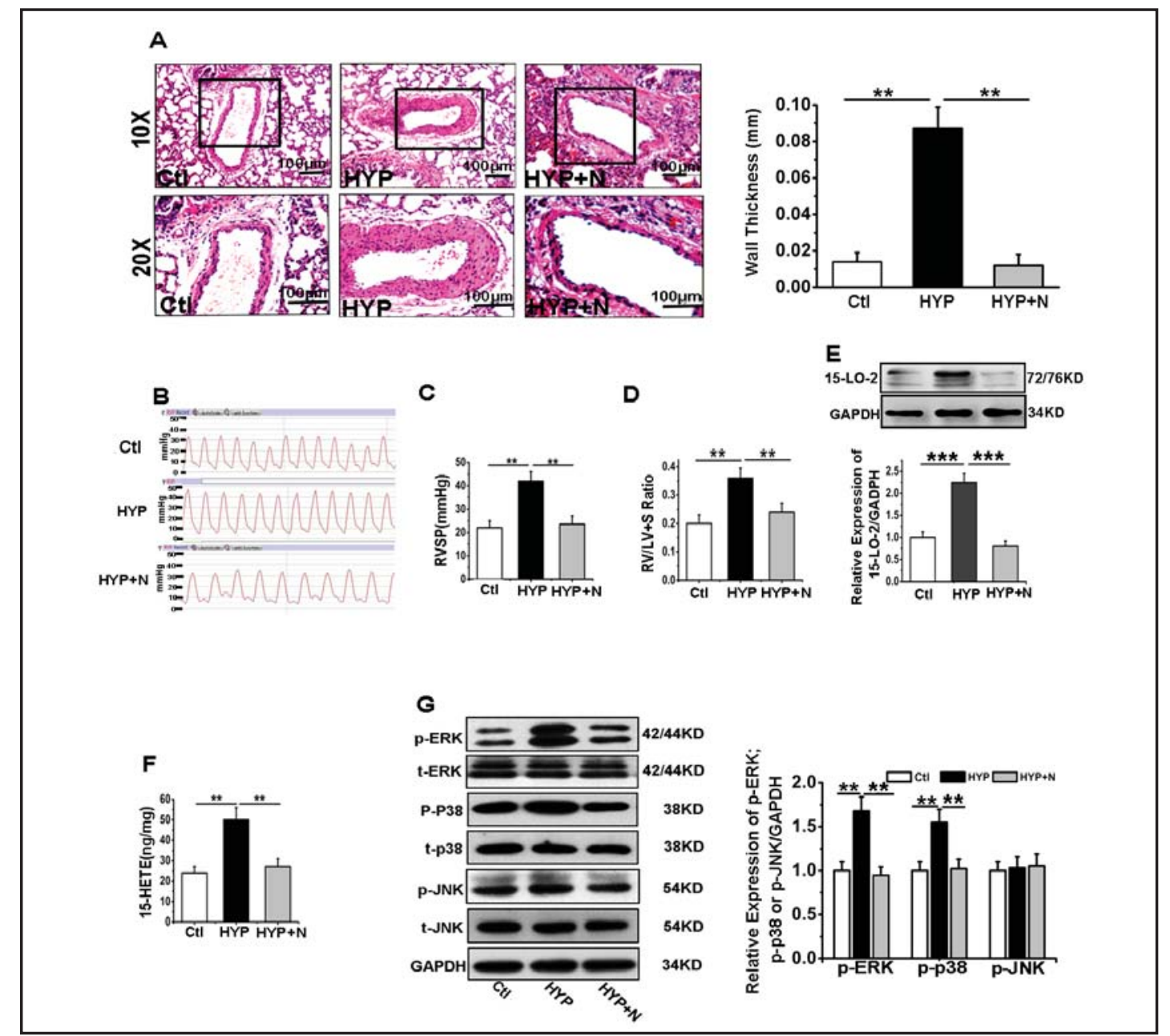

Fig. 2. A: The HE staining showed that hypoxia significantly increased the medial wall thickness $\left({ }^{* *} P<0.01\right.$; $\mathrm{n}=5$ ). B: Representative tracings of RV pressures in normoxic, chronically hypoxic rat and chronically hypoxic rat treated with NDGA. C: Bar graphs (means \pm SEM) showed the result of RVSP in hypoxic model $\left({ }^{* *} P<0.01 ; \mathrm{n}=5\right)$. D: Bar graphs (means $\pm \mathrm{SEM}$ ) showed $\mathrm{RV} / \mathrm{LV}+\mathrm{S}$ weight ratio in rat exposed to normoxia or hypoxia in the absence or presence of NDGA $\left({ }^{* *} P<0.01 ; n=5\right)$. E:The expression of $15-\mathrm{LO}-2$ in vessels of rats from hypoxia model $(* * * p<0.001 ; \mathrm{n}=5)$. F: The endogenous level of 15-HETE measured by 15-HETE EIA kit in rat ( $\left.{ }^{* *} P ; 0.01 ; \mathrm{n}=5\right)$. G: The protein expression of MAPK in vessels of hypoxic rat model $(* * P<0.01 ; \mathrm{n}=5)$. Bars are presented as mean \pm SEM. "Ctl" means control; "HYP"means hypoxia; "HYP+N"means "hypoxia+NDGA".

that the expression of 15-LO-2 were markedly up-regulated in pulmonary arterials of the $\mathrm{PH}$ patients in comparison with that of normal tissues (Fig. 1D). Furthermore, ELISA showed that the level of endogenous 15-HETE was drastically elevated in pulmonary arteries from human PH (Fig. 1E). On the other hand, MAPKs expression was detected the protein levels of phosphorylated extracellular signal-regulated kinase (p-ERK) and phosphorylated p38 mitogen-activated protein kinases (p-p38MAPK), but not phosphorylated c-Jun N-terminal kinase (p-JNK), were enhanced in pulmonary arteries of human PH patients (Fig. 1F). These data suggest that 15-LO-2/15-HETE and MAPKs somehow implicated in the pulmonary arterials remodeling during development of $\mathrm{PH}$.

15-LO inhibition prevented hypoxic PH and the expression of MAPKs signaling in hypoxic PH in rats

Hypoxic induced PH rat model was used to test whether 15-LO-2/15-HETE and MAPKs involved in pulmonary arterials remodeling. Similar remodeling of medium-size pulmonary 


\section{Cellular Physiology Cell Physiol Biochem 2015;35:2079-2097 \begin{tabular}{l|l} 
DOI: 10.1159/000374015 & $\begin{array}{l}\text { O 2015 S. Karger AG, Basel } \\
\text { www.karger.com/cpb }\end{array}$ \\
\hline
\end{tabular}}
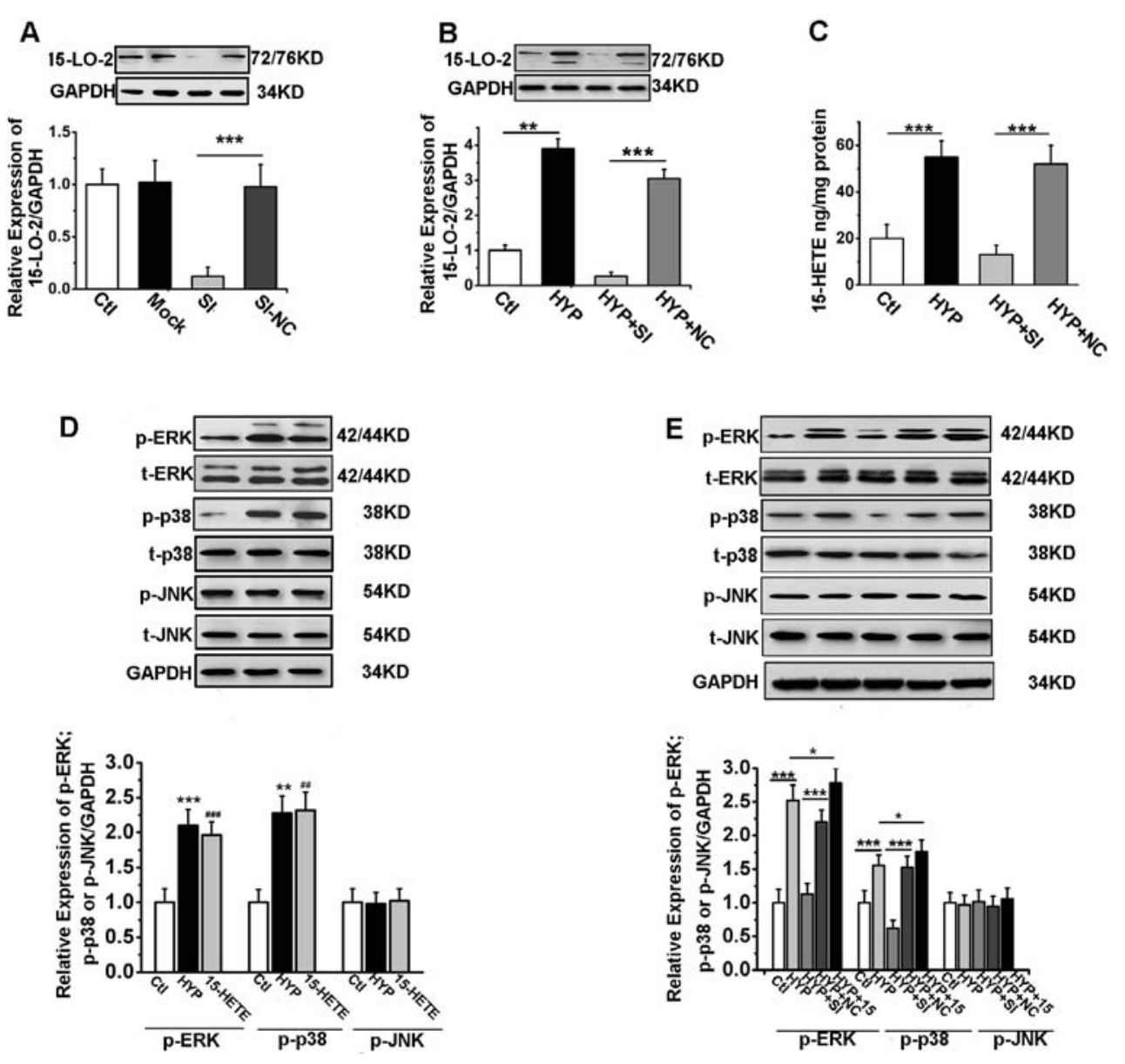

Fig. 3. A: The efficiency and specificity of RNA interference. Intracellular expression of 15-LO-2 treated with SI-NC was not different from expression in untreated control cells or cells treated with the transfection reagent alone $\left({ }^{* * *} P<0.001 ; \mathrm{n}=6\right)$. B: The expression of $15-\mathrm{LO}-2$ in PASMCs of rats under hypoxia $\left({ }^{* *} P<0.01\right.$; $\left.{ }^{* * *} P<0.001 ; \mathrm{n}=6\right)$. C: The endogenous level of 15-HETE measured by 15-HETE EIA kit in PASMCs of rats $\left({ }^{* * *} P<0.001 ; \mathrm{n}=6\right)$. D: the expression of $\mathrm{p}$-ERK and p-p38MAPK in PASMCs of rats treated with 15-HETE (1 $\mu \mathrm{mol} / \mathrm{L})$ under the normoxic condition ( ${ }^{* *} P<0.01$; ${ }^{* * *} P<0.01$; ${ }^{* \#} P<0.01$; \#\#\# $\left.P<0.001 ; \mathrm{n}=6\right)$. E: The expression of MAPK in the PASMCs of rats treated with SI-RNA targeting at 15 -LO-2 at protein level $\left({ }^{*} P<0.05\right.$; ${ }^{* * *} P<0.001 ; \mathrm{n}=6$ ). Bars are presented as mean \pm SEM. "Ctl"means control; "HYP" means hypoxia; "SI" means SI-RNA targeted at 15-LO-2;"NC"means Negative control.

arteries was found in rats exposed to hypoxia for 9 days, wall thickening significantly increased compared with normoxic rats. The increasing was inhibited by administration of NDGA, a lipoxygenase inhibitor (Fig. 2A). RV pressure and heart weights were used to evaluate the effects of NDGA on the development of hypoxic PH. Hypoxia significantly elevated RVSP and RV/LV+S in rats, while the elevation was reversed by NDGA (Fig. 2B, C, D). We measured the expression of 15-LO-2 in tissue levels. Hypoxia augmented the protein expressions of 15-LO-2, whereas NDGA reversed this effect (Fig. 2E). In addition, endogenous 15-HETE was identified by ELISA. In consistent with the increased expression of 15-LO-2, the 15-HETE level in pulmonary arteries was increased in hypoxic rats, the increasing was reversed by administration of NDGA (Fig. 2F).Consistent with the observation from human $\mathrm{PH}$ patients, hypoxia augmented the protein expressions of p-ERK and p-p38MAPK, but not p-JNK, in rat pulmonary arteries, and the increasing expression of p-ERK and p-p38MAPK were decreased by administration of NDGA (Fig. 2G). These results indicated that 15-LO- 


\section{Cellular Physiology Cell Physiol Biochem 2015;35:2079-2097 \begin{tabular}{l|l} 
DOI: $10.1159 / 000374015$ & \\
and Biochemistry Published online: April 07, 2015 & $\begin{array}{l}\text { (2) } 2015 \text { S. Karger AG, Basel } \\
\text { www.karger.com/cpb }\end{array}$ \\
\cline { 2 - 3 }
\end{tabular}

\section{A}

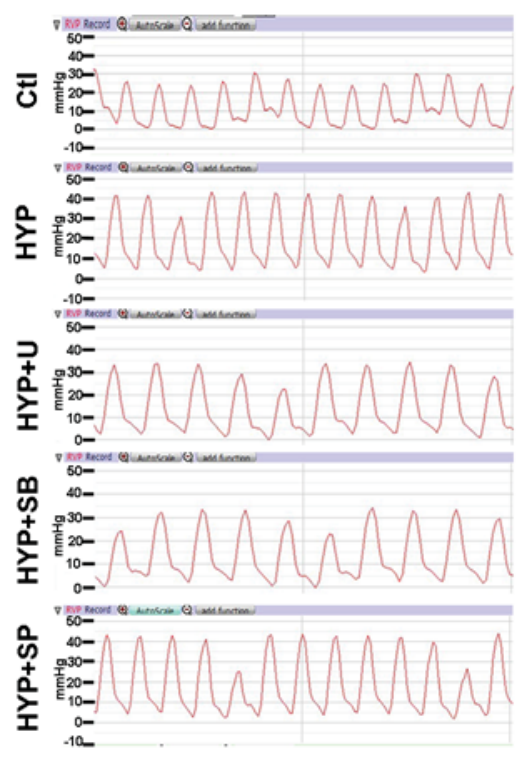

B

C
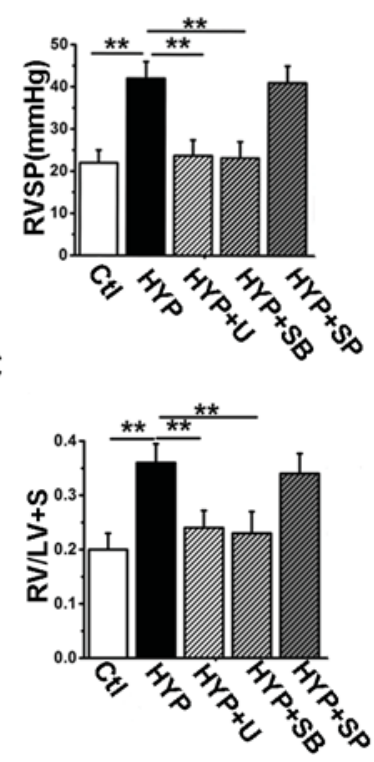

Fig. 4. A: Representative tracings of RV pressures in normoxic, chronically hypoxic rat and chronically hypoxic rat treated with U0126, SB203580 and Sp600125 respectively. B: Bar graph (means \pm SEM) showed the results of RVSP in hypoxic models $\left({ }^{* *} P<0.01 ; n=6\right)$. C: Bar graphs (means \pm SEM) showed RV/ $\mathrm{LV}+\mathrm{S}$ weight ratio in rat exposed to normoxia or hypoxia in the absence or presence of U0126, SB203580, Sp600125(** $P<0.01 ; \mathrm{n}=6)$. Bars are presented s mean \pm SEM.“Ctl"means control; "HYP"means hypoxia; "N"means NDGA; "15" means 15-HETE.

2/15-HETE pathways were involved in the pathological process of PAH through activated ERK and p38MAPK.

15-LO-2/15-HETE induced the expression of MAPKs in rat PASMCS

To exam the role of 15-LO-2/15-HETE on regulate MAPK pathway in rat PASMCs, we knocked down the 15-LO-2 by RNA interference. As shown in the Fig. 3A, the RNA interference was able to knockdown 15-LO-2, however, neither the SI-NC nor the transfection reagent alone did not significantly affect the intracellular expression of 15-LO-2. Hypoxia significantly increased the expression of 15-LO-2 in rat PASMCs and the RNA interference could reduce 15LO-2 expression in hypoxic conditions (Fig. 3B). In consistent with the increased expression of 15-LO-2, the 15-HETE level was increased in hypoxic conditions, and the RNA interference could reduce the generation of 15-HETE (Fig. 3C). Next, we measured the expression of p-ERK and p-p38MAPK under hypoxic and normoxic conditions, the results indicated that the p-ERK and p-p38MAPK were increased by treated with exogenous 15-HETE or hypoxia (Fig. 3D). More importantly, the increased expression of p-ERK and p-p38MAPK induced by hypoxia were reduced after silencing 15-LO-2 (Fig. 3E). These results indicated that 15-LO2/15-HETE mediated hypoxia-increased the phosphrolation of MAPKs in rat PASMCs.

MAPKs inhibition prevented hypoxic $P H$

RV pressure readings (Fig. 4A) and heart weights were used to evaluate the effects of MAPKs inhibitors on the development of PAH. RVSP was significantly elevated in hypoxic rats compared to normotensive rats. Administration of U0126 or SB203580, but not sp600125 significantly reduced the increasing RVSP (Fig.4B). Similar results were observed in the percent of RV weight by normalized to $\mathrm{LV}+\mathrm{S}$ weight (RV/LV+S) (Fig. 4C). 


\section{Cellular Physiology Cell Physiol Biochem 2015;35:2079-2097 \begin{tabular}{l|l|l|l|l|l}
\hline DOI: 10.1159/000374015 & 015 S. Karger AG, Basel
\end{tabular} and Biochemistry Published online: April 07, 2015 www.karger.com/cpb}

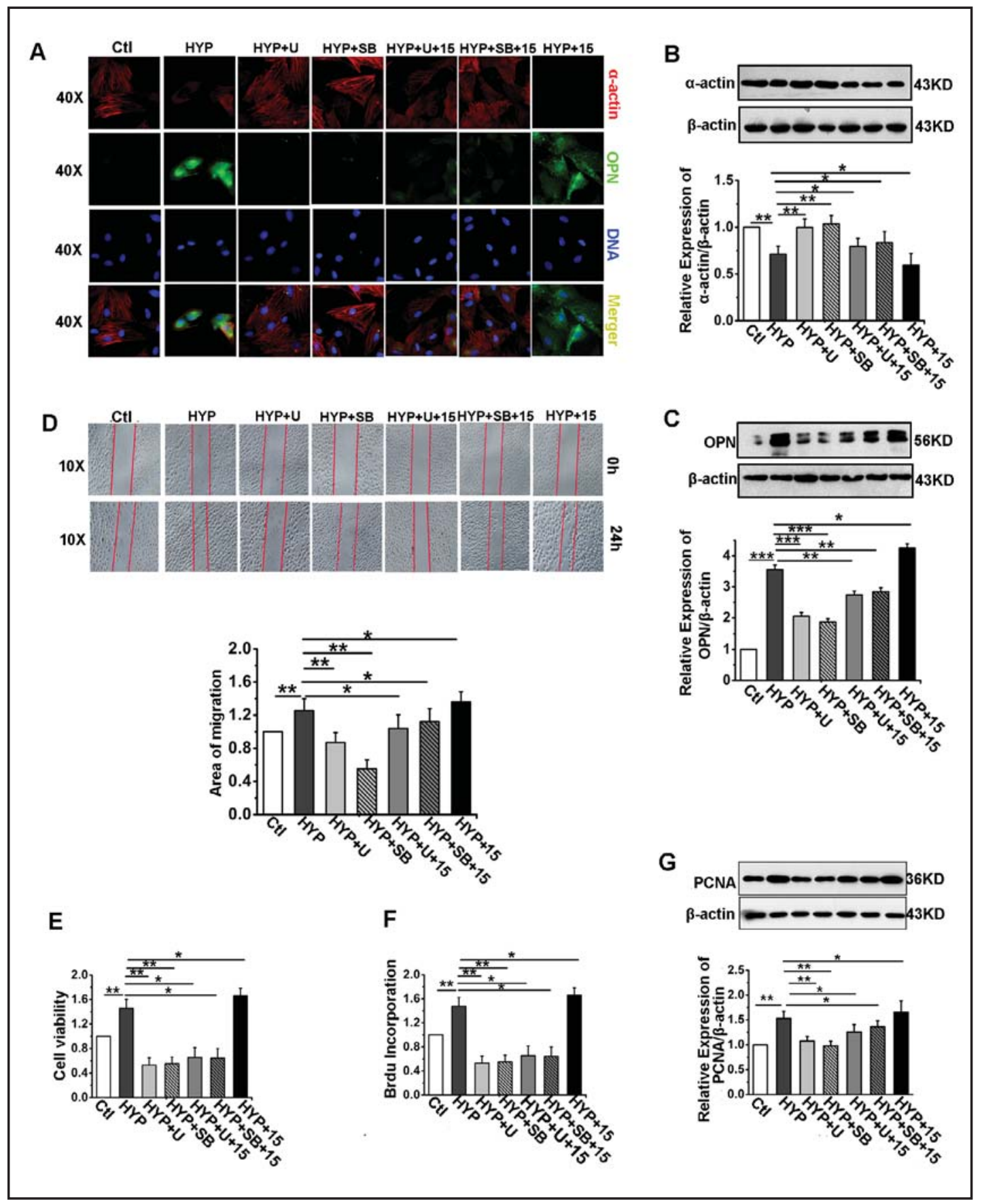

Fig. 5. A: Immunofluorescence evaluation of the expression of $\alpha$-actin and OPN in PASMCs of rats under different treatment conditions. Scale bars are $50 \mu \mathrm{m}$. B: The decreased expression of $\alpha$-actin induced by hypoxia was rescued significantly by the inhibitor of ERK (U0126) and inhibitor of P38 (SB203580) in PASMCs of rats $\left({ }^{*} P<0.05 ;{ }^{*} \mathrm{P}<0.01 ; \mathrm{n}=6\right)$. C: The increased expression of OPN under hypoxia was reduced markedly after U0126 $(5 \mu \mathrm{mol} / \mathrm{L})$ and SB203580 $(5 \mu \mathrm{mol} / \mathrm{L})$ treatment in PASMCs of rats $\left({ }^{*} P<0.05 ;{ }^{* *} P<0.01\right.$; $\left.{ }^{* * *} P<0.001 ; \mathrm{n}=6\right)$. D: Scratch-wounding cell migration assay. The migration induced by hypoxia was blocked byU0126 or SB203580 in PASMCs of rats. Scale bars are $20 \mu \mathrm{m}\left({ }^{*} P<0.05 ;{ }^{*} P<0.01 ; n=3\right)$. E: The cell viabi-

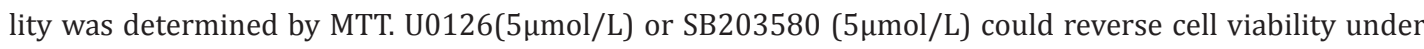
hypoxia $\left({ }^{*} P<0.05 ;{ }^{*} P<0.01 ; \mathrm{n}=6\right)$. F: BrdU incorporation assay was examined under hypoxic condition with the treatment of U0126 ( $5 \mu \mathrm{mol} / \mathrm{L})$ or SB203580 (5 $\mu \mathrm{mol} / \mathrm{L})\left({ }^{*} P<0.05 ; \mathrm{n}=6\right)$. G: High expression of PCNA under hypoxia was decreased in the presence of U0126 (5 $\mu \mathrm{mol} / \mathrm{L})$ or SB203580 $(5 \mu \mathrm{mol} / \mathrm{L})$ in PASMCs of 


\section{Cellular Physiology Cell Physiol Biochem 2015;35:2079-2097 \begin{tabular}{l|l|}
\hline DOI: 10.1159/000374015 & O 2015 S. Karger AG, Basel
\end{tabular} and Biochemistry Published online: April 07, $2015 \quad$ www.karger.com/cpb \\ Yu et al.: Role of MAPKs in Pulmonary Vascular Remodeling}

rats $\left({ }^{*} P<0.05 ; \mathrm{n}=6\right)$. In all the experiments the concentration of exogenous 15 -HETE was $1 \mu \mathrm{mol} / \mathrm{L}$. Bars are presented s mean \pm SEM. "Ctl” means control; "HYP" means hypoxia; "U" means "U0126"; "SB" means "SB203580"; "15” means 15-HETE.

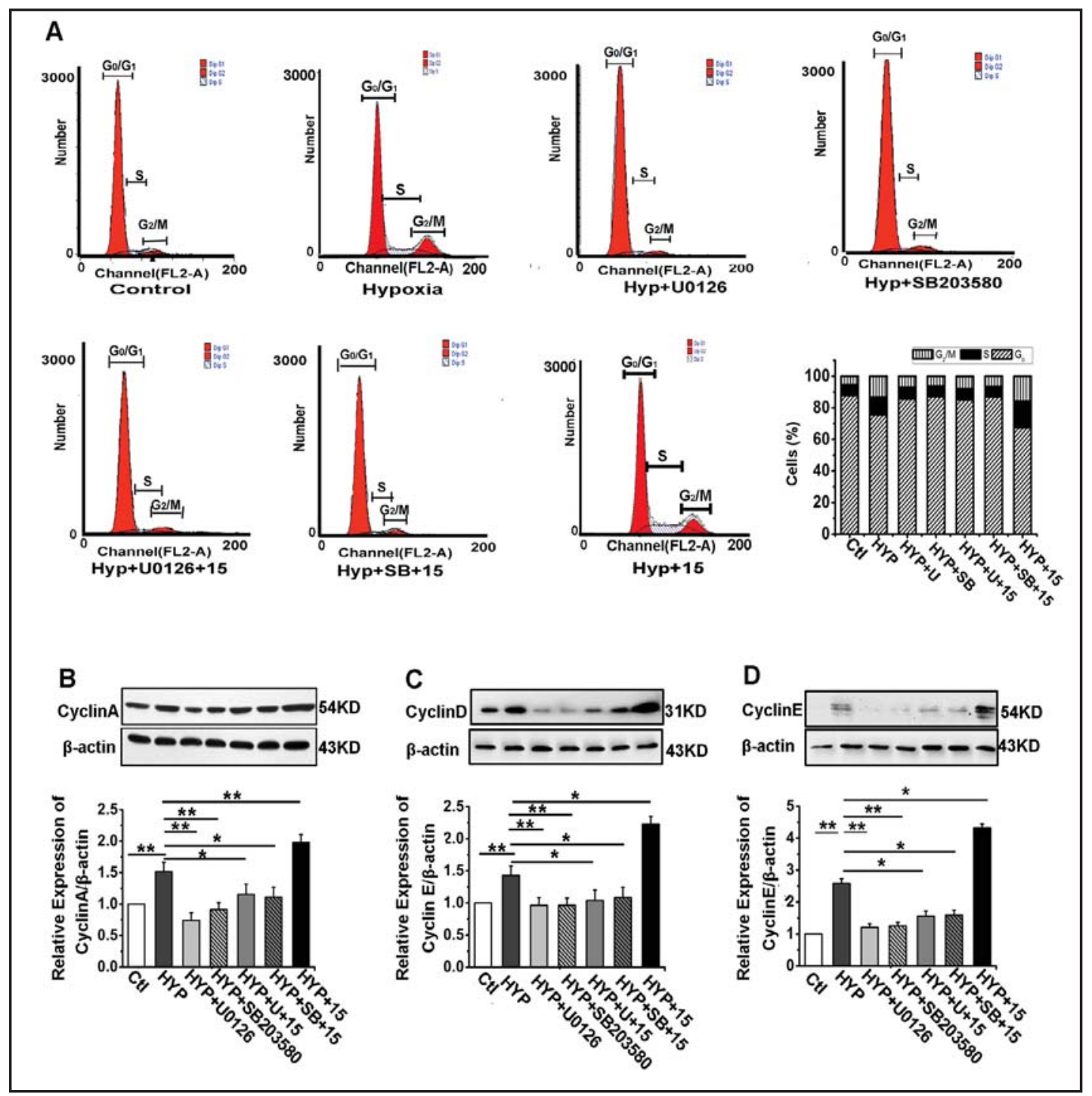

Fig. 6. A: Hypoxia increased the cell number in the $S$ and G2/M phases compared with normoixa. This effect was reversed by U0126 ( $5 \mu \mathrm{mol} / \mathrm{L}$ ) and SB203580 (5 $\mu \mathrm{mol} / \mathrm{L}$ effect was). B-D: The expression of cyclinA, cyclinD1 and cyclinE were studied in PASMCs of rats. The effect of endogenous 15-HETE on cyclinA, cyclinD1 and cyclinE were reversed by U0126 (5 $\mu \mathrm{mol} / \mathrm{L})$ or SB203580 (5 $\mu \mathrm{mol} / \mathrm{L})$ under hypoxia in PASMCs of rats $\left({ }^{*} P<0.05 ;{ }^{*} \mathrm{P}<0.01 ; \mathrm{n}=6\right)$. The concentration of exogenous 15 -HETE was $1 \mu \mathrm{mol} / \mathrm{L}$ in all the experiments. Bars are presented s mean \pm SEM."Ctl”means control; "HYP"means hypoxia; "SB" means "SB203580"; "15" means 15-HETE.

15-HETE promoted trans-differentiation; migration and proliferation of PASMCs was mediated by $M A P K$

In response to hypoxia/ high phosphate stimulus, the expression of SMC differentiation marker genes smooth muscle (SM) $\alpha$-actin is decreasing and expression of osteogenic genes such as osteopontin (OPN) is increasing, which known as phenotypic changes [33, 34]. In order to confirm whether ERK and p38MAPK pathways were involved in the 15-LO-2/15- 


\section{Cellular Physiology Cell Physiol Biochem 2015;35:2079-2097 \begin{tabular}{l|l|l}
\hline DOI: 10.1159/000374015 & O 2015 S. Karger AG, Basel
\end{tabular} and Biochemistry Published online: April 07, 2015 www.karger.com/cpb

Fig. 7. A: The MAPK pathway mediating 15-HETE-protected apoptosis was determined by flow cytometer. The results showed that the increase of apoptotic cells were depressed by exogenous 15-HETE (1 $\mu \mathrm{mol} / \mathrm{L})$. However, U0126 (5 $\mu \mathrm{mol} / \mathrm{L})$ or SB203580 (5 $\mu \mathrm{mol} / \mathrm{L}$ ) reversed this effect. Bars are presented as mean \pm SEM. $\left({ }^{* *} P<0.01 ; \quad * * * P<0.001\right.$; $\mathrm{n}=3$ ). "SD" means serum deprivation; "Ctl"means control; "U" means "U0126"; "SB" means "SB203580"; "15" means 15-HETE.
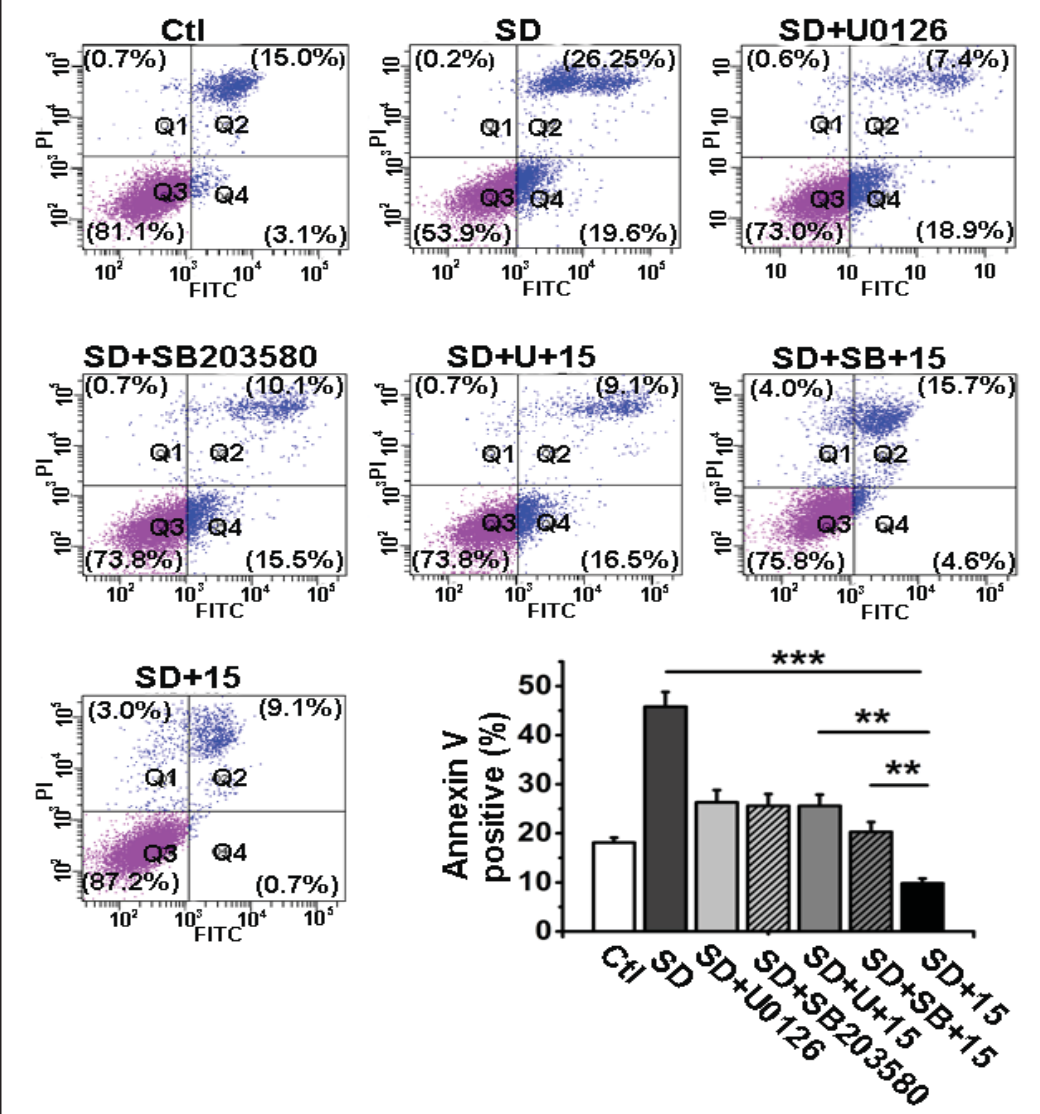

HETE-induced PASMC phenotypic changes, we performed immunofluorescence staining against $\alpha$-actin and OPN. Hypoxia increased OPN expression and decreased $\alpha$-actin level. Both effects were greatly reversed by U0126 or by SB203580 (Fig. 5A). Similar effect were found in immunoblotting experiment, the down-regulation of $\alpha$-actin and up-regulation of OPN induced by hypoxia was also abolished by ERK or P38MAPK inhibitors in rats PASMCs (Fig. 5B \& 5C).

In the scratch-wound assay, the migration induced by hypoxia was significantly inhibited by U0126 or SB203580. In addition, exogenous 15-HETE did not reverse the effects of MAPK inhibitors on differentiation and migration of PASMCs (Fig. 5D).

To elucidate the effect of ERK and p38MAPK signaling pathways on rat PASMCs proliferation, which is a key component of PVR, we suppressed ERK and p38MAPK by U0126 and SB203580 respectively in cultured rat PASMCs under hypoxia condition, then measured the cell viability, Brdu incorporation and the expression of proliferating cell nuclear antigen (PCNA). Hypoxia significantly increased the cell viability, and the Brdu incorporation, both the increasing effects was significantly suppressed by either U0126 or SB203580 (Fig. 5E-5F). The upregulation of PCNA expression induced by hypoxia was also abrogated by the ERK and p38MAPK inhibitors (Fig. 5G). Consistent with the observation in migration experiments, exogenous 15-HETE did not reverse the effects of MAPK inhibitors on proliferation of rat PASMCs. These data indicated that the effect of 15-LO-2/15-HETE on proliferation of PASMCs is likely mediated by ERK and p38MAPK signaling pathways.

MAPKs participated in the Cell-cycle transition from G0/G1 Phase to S Phase plus G2/M phase in rat PASMCS, which was Forward Catalyzed by 15-HETE

To elucidate whether the ERK and P38MAPK signaling pathways participate in15HETE-mediated cell cycle activity, the number of cells in each phase of cell cycle was detected by flow cytometry. Hypoxia-induced cell proliferation was demonstrated by an 

Cellular Physiology Cell Physiol Biochem 2015;35:2079-2097 \begin{tabular}{l|l}
\hline DOI: 10.1159/000374015 & (c) 2015 S. Karger AG, Basel
\end{tabular} and Biochemistry Published online: April 07, $2015 \quad$ www.karger.com/cpb

A
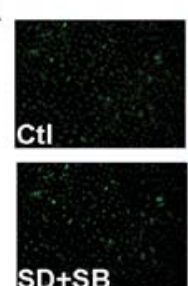

$\mathrm{SD}+\mathrm{SB}$
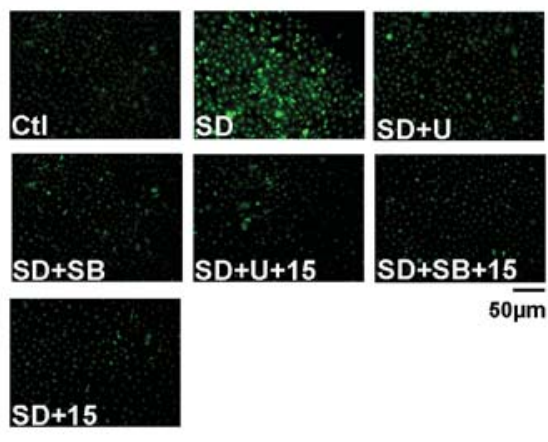

$50 \overline{\mu m}$

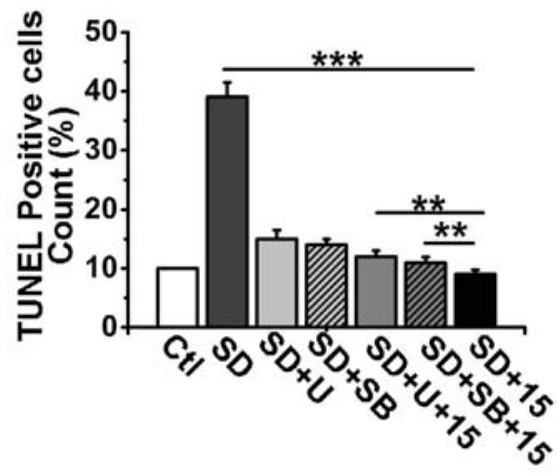

C

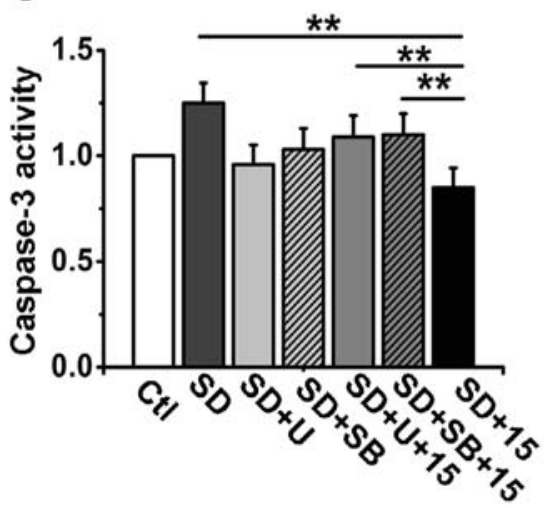

B
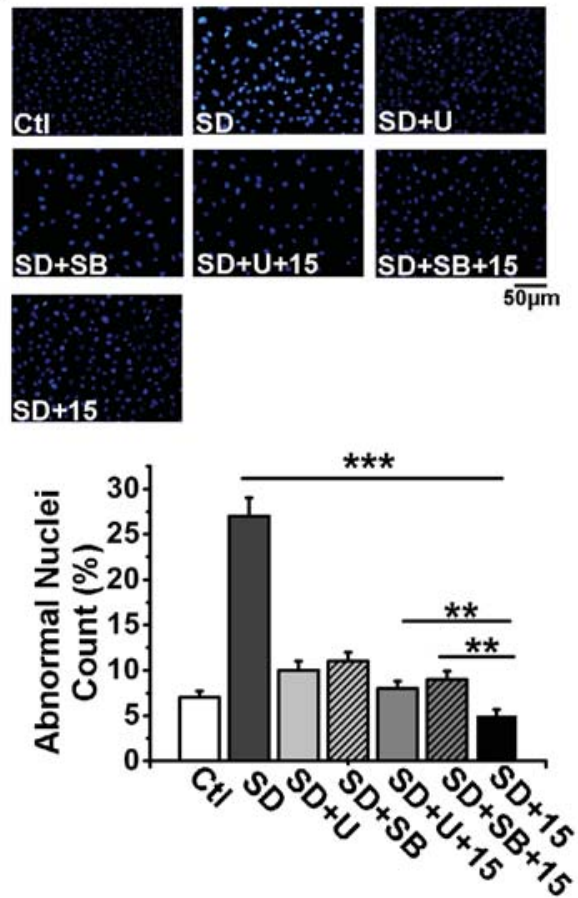

D

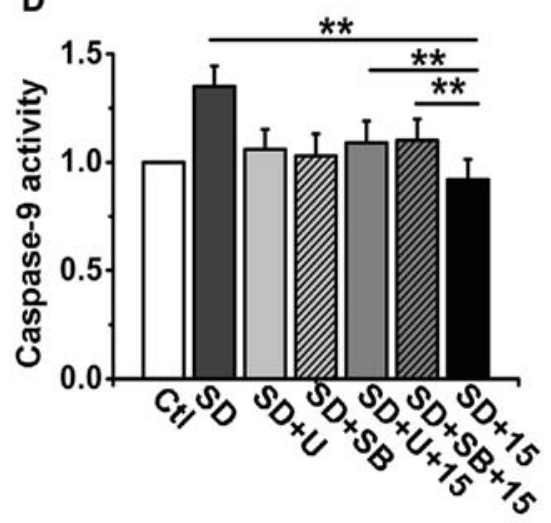

Fig. 8. A: 15-HETE decreased the number of TUNEL-positive cells via MAPK pathway in PASMCs. Scale bars are $50 \mu \mathrm{m}$. B: Exogenous 15-HETE $(1 \mu \mathrm{mol} / \mathrm{L})$ protected against nuclear morphology changes caused by serum deprivation (SD) in a MAPK-dependent manner. Scale bars are $50 \mu \mathrm{m}$. C-D: The inhibition effects of 15-HETE on caspase- 3 and caspase- 9 activation were weakened in the presence of U0126 $(5 \mu \mathrm{mol} / \mathrm{L})$ or SB203580 ( $5 \mu \mathrm{mol} / \mathrm{L})$. Bars are presented as mean \pm SEM. $\left({ }^{* *} P<0.01 ;{ }^{* * *} P<0.001 ; \mathrm{n}=3\right)$. "SD" means serum deprivation; "Ctl” means control; "U” means "U0126"; "SB" means "SB203580"; "15" means 15-HETE.

increased percentage of cells entering S-phase plus $\mathrm{G}_{2} / \mathrm{M}$ phase. The amount of $S$ phase cells and $G_{2} / M$ phase cells together was significantly reduced and the percentage of $G_{0} / G_{1}$-phase cells was increased when treated with U0126 or SB203580 respectively (Fig. 6A). Since cyclin-A, cyclin-D1 and cyclin-E play important roles in both the $S$ and $G_{2} / M$ phases [35], we analyzed the posttranslational levels of cyclin-A, cyclin-D1 and cyclin-E in rat PASMCs. A significant reduction in the expression of cyclin-A, cyclin-D1 and cyclin-E was observed after treating U0126 or SB203580 respectively (Fig. 6B, 6C, 6D). However, exogenous 15-HETE could not reverse the effects of MAPK inhibitors on regulate cell cycle of rat PASMCs. These 


\section{Cellular Physiology Cell Physiol Biochem 2015;35:2079-2097 \begin{tabular}{l|l} 
DOI: 10.1159/000374015 & $\begin{array}{l}\text { O 2015 S. Karger AG, Basel } \\
\text { www.karger.com/cpb }\end{array}$ \\
\hline
\end{tabular}

Fig. 9. Diagram of the possible cascade of event involved MAPK and 15-LO/15-HETE. The 15-LO/15-HETE inhibition by NDGA leads to the reduced expression of p-ERK or p-p38MAPK. This effect is engaged in the progression of PASMCs apoptosis, proliferation, migration, trans-differentiation and cell cycle distribution, participating in pulmonary vascular remodeling associated with $\mathrm{PH}$.

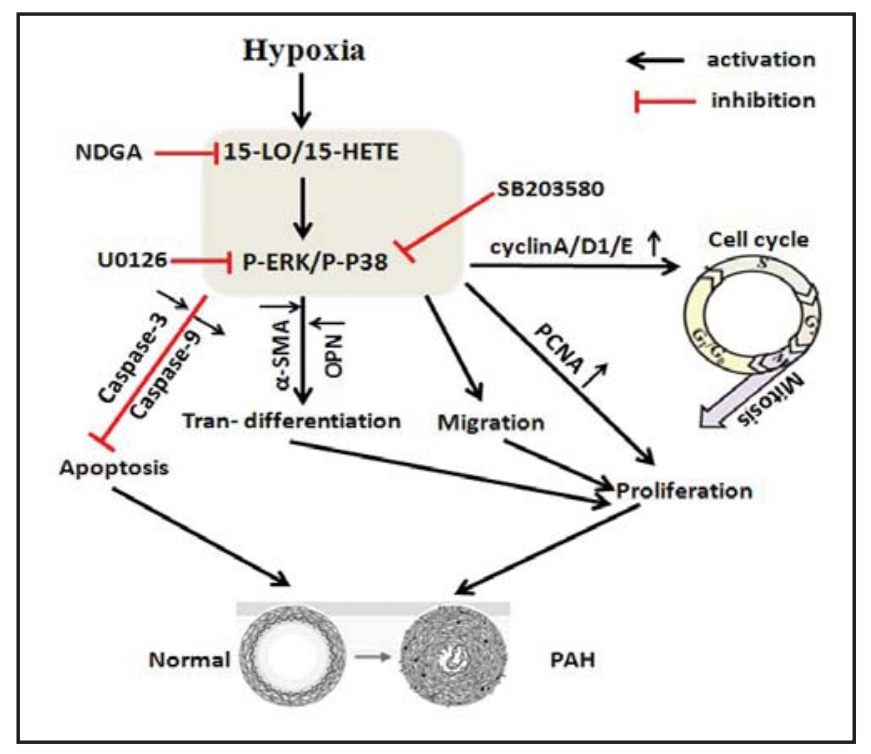

data showed that the 15-LO-2/15-HETE/MAPK was involved in the cell cycle regulation rat PASMCs.

\section{5-HETE protected rat PASMCs from apoptosis through MAPK}

As both the increase of proliferation and the decrease of apoptosis in rat PASMCs can lead to the pulmonary arterial medial hypertrophy, we applied serum deprivation (SD) as an apoptotic approach to study whether MAPKs participated in the anti-apoptotic effects on rats PASMCs under hypoxic condition. As shown in Fig. 8, SD produced a large population of Annexin V-positive cells (from $17.9 \pm 0.4 \%$ to $45.45 \pm 0.5 \%$ ), and the percentage of apoptotic cells was reduced to $9.1 \pm 0.9 \%$ by 15 -HETE as determined by flow cytometer. However, the protection effects of 15-HETE on cell apoptosis were attenuated in the presence of U0126 or SB203580 (24.9 $\pm 0.7 \%$ and $19.9 \pm 0.6 \%$ respectively, Fig. 7). Besides, SD increased the TUNELpositive cells in PASMCs, which was also inhibited by 15-HETE in an MAPK dependent manner (Fig. 8A). Moreover, the nuclear morphology indicated by Hoechst stain (Fig. 8B), confirmed that the 15-HETE inhibited SD-induced apoptosis in PASMCs, and the inhibitory effect of 15HETE was attenuated by ERK inhibitors or p-38MAPK inhibitors. In addition, the increase of caspase-3 and capase-9 activities was observed in serum deprivation PASMCs, and 15HETE restrained the caspase- 3 and caspase- 9 activation, the inhibitory effect of 15-HETE was significantly attenuated by either U0126 or SB203580 (Fig. 8C-8D). Taken together, the ERK and p38MAPK pathways were necessary for the inhibition effect of 15-HETE on SDinduced apoptosis.

\section{Discussion}

We have been proved that hypoxia induced pulmonary vascular remodeling is mediated by 15-HETE $[7,29]$. However, the molecular mechanisms underlying 15-HETE mediated pulmonary remodeling still not fully understand. Recent studies suggested that MAPKs contributed to the hypoxia-induced PH development and the associated pulmonary vascular remodeling. Here we demonstrated that the expression of 15-LO-2, p-ERK and p-p38MAPK were enhanced in the pulmonary vasculature of $\mathrm{PH}$ patients. By using hypoxia-induced $\mathrm{PH}$ rat models and in vitro culture rat PASMCs, we further elucidated that the 15-LO-2/15-HETEMAPKs pathway underlying hypoxia-induced pulmonary vascular remodeling through regulation of PASMC trans-differentiation, migration, proliferation/apoptosis and cell cycle progress. 


\section{Cellular Physiology Cell Physiol Biochem 2015;35:2079-2097 \begin{tabular}{ll|l} 
and BO 10.1159/000374015 & $\begin{array}{l}\text { C 2015 S. Karger AG, Basel } \\
\text { www.karger.com/cpb }\end{array}$ \\
\hline
\end{tabular}}

In our study, we found that the expression of p-ERK and p-p38MAPK were increased in pulmonary vascular of PAH patients. These results indicated that ERK and p38MAPK signaling pathways were involved in the pathological process of PAH. And the effects of MAPKs inhibitors (U0126, SB20358, sp600125) were first time evaluated on the development of PAH. The U0126 or SB203580 could ameliorate hypoxia-elevated RVSP and Right ventricular hypertrophy. Evidently, the inhibition of ERK and p38MAPK by administrating a chemical inhibitor prevented and reversed the experimental PAH. These results are consistent with the previous study, which showing that activation of ERK and p38MAPK appears to be associated with hypoxia-induced pulmonary vascular remodeling [9].

In our previous studies, we have found that 15-HETE mediates pulmonary adventitia fibrosis, pulmonary vascular remodeling, and angiogenesis $[25,28,29]$. In the current study we found that $\mathrm{p}$-ERK and p-p38MAPK expression was reversed in pulmonary vasculatures by NDGA (a lipoxygenase inhibitor) in hypoxia-induced PH rat (Fig. 2G). Moreover, hypoxia increase the phosphorylation of ERK and p38MAPK, the effect is inhibiting by siRNA targeted 15-LO-2 in cultured rat PASMCs (Fig. 3D-3E). These results indicate that 15-LO-2/15HETE was essential for hypoxia- activated ERK and p38MAPK in PASMCs.

Previous studies have shown that chronic hypoxia induced phenotypical switches of the PASMCs from the contractile and well differentiated phenotype to the synthetic and dedifferentiated phenotype [36]. Such alterations caused the vascular SMCs to regain their proliferative and migratory capacities and also enable their capability to secrete matrix proteins [36]. These pathological processes appear to be related to the PAH. In this study, we indicated that chronic hypoxia suppresses the expression of $\alpha$-SMA and augments the expression of OPN. And this phenotype switching is largely eliminating by ERK or p38MAPK inhibitor (U0126 or SB203580). Meanwhile, the results also show thatp-ERK and p-p38MAPK promoted the migration of PASMCs.

Increased phosphorylation of ERK and p38MAPK mediates hypoxia-increased the proportion of cells in the $S$ and $G_{2} / M$ phases in PASMCs. The process may be through direct or indirect stimulation of cyclin A, cyclin D1 and cyclin E expression, all of which are known to regulate the cell cycle progression and play important roles in the both $S$ and $G_{2} / M$ phases. The information thus provided direct evidence that p-ERK and p-p38MAPK activate cell cycle progression. This was support by the finding that inactivation of ERK may lead to cell cycle arrest in cancer cells [37]. Secondly, p38MAPK signaling also modulate mammalian cell cycle by antagonizing the effects of ERK mediated Cyclin D expression and thus regulating the G1/ S cell cycle arrest [37].

The pathologic processes of pulmonary vascular remodeling were correlated with the promoted PASMCs proliferation and suppressed PASMCs apoptosis. We confirmed that activation of p38MAPK or ERK, promoted PASMCs phenotype changed caused the PASMCs migration and proliferation. In addition, the p38MAPK and ERK regulated the cell cycle progression, which increased medial thickening and leads to vascular remodeling. Besides, p38MAPK and ERK inhibited the PASMCs apoptosis. Overall, it is clearly described the first time that the MAPK signaling pathways participate in the pathological process of hypoxiainduced pulmonary fibroblast and PASMCs proliferation and vascular remodeling.

Previous reports have showed that 5-hydroxytryptamine (5-HT) stimulated PASMCs proliferation and migration by activating JNK [24]. However, our results identify that there were no changed in the expression of p-JNK in the pulmonary arterial from both PAH patients and rat PAH models. We purposed that phosphorylation of JNK might be correlated with pulmonary vessels response to prophase of hypoxia, but not the later stage. This was support by the finding that phosphorylation of JNK was maximal activated at day 1 and disappeared after 7 day of hypoxia [9].

A limitation in our study is the using of NDGA as 15-LO inhibitor. NDGA is a nonselective lipoxygenase inhibitor which blocks cysteinyl-leuotriene synthesis. The IC50 values are 3.0-5.0 $\mu \mathrm{M}$ for human platelet 12-lipoxygenase and $0.91 \mu \mathrm{M}$ for rabbit reticulocyte 15 -lipocygenase; $0.2 \mu \mathrm{M}$ for 5 -lipoxygenase [38, 39]. The dose tested in this study was $1 \mu \mathrm{M}$ for rat PASMCs 15-lipocygenase, which limited the off-targets inhibition of NDGA on other 


\section{Cellular Physiology Cell Physiol Biochem 2015;35:2079-2097

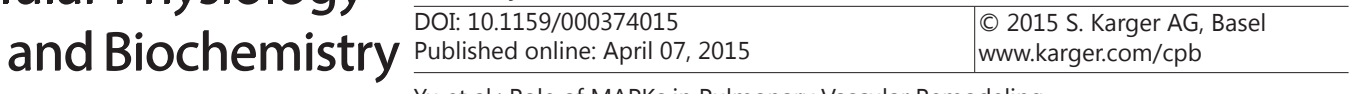 \\ Yu et al.: Role of MAPKs in Pulmonary Vascular Remodeling}

lipoxygenase. Moreover, in order to compensate for this limitation, we used the specificity of RNA interference target at 15-LO-2 in cellular level. The consistent effects of siRNA and NDGA suggest 15-LO-2 maybe the important factor involved in hypoxia-induced pulmonary arterials remodeling. However, further studies on cell or tissue specific knockout animal models (lung or SMCs 15-LO-2 knockout) will reinforce the pathophysiology effects of 15-LO-2/15-HETE on hypoxia-induced pulmonary vascular remodeling.

We have discovered 15-LO-2/15-HETE acts as a novel upstream signals target to regulate MAPK pathways, which are engaged in the progression of PASMCs apoptosis/ proliferation, migration, trans-differentiation and cell cycle distribution, and implicated in pulmonary vascular remodeling (Fig. 9). Inhibition of MAPK pathways and 15-LO-2 specific in pulmonary vessels may ameliorate the morbidity and mortality in patients with $\mathrm{PH}$.

\section{Abbreviations}

15-LO (15-lipoxygenase); 15-HETE (15-hydroxyeicosatetraenoic acid); $\alpha$-actin $(\alpha$-smooth muscle-actin); ERK (extracellular signal-regulated kinase); JNK (Jun N-terminal kinase); MAPKs (mitogen-activated protein kinases); NDGA (nordihydroguaiaretic acid); PH (pulmonary hypertension); PVR (pulmonary vascular resistance); RVSP (right ventricular systolic pressure); VSMCs (vascular smooth muscle cells).

\section{Acknowledgments}

This work was supported by the National Natural Science Foundation of China (81270113; 331071007; 31100835); Graduate Innovation Foundation of Heilongjiang Province (Contract grant number: YJSCX 2012-248HLJ); Specific Science Foundation for PhD Training Program of Ministry of Education of China (Contract grant number: 20112307110022); Science and Technique Foundation of Daqing of China (Contract grant number: DQGX2011KJ002); Key Research Plan of Heilongjiang Province of China (Contract grant number: GC10C206); Key Research Plan of Daqing of China (Contract grant number: SGG2011-05). We thank Dr Chun Jiang at Georgia State University, Atlanta, GA, U.S.A. for his comments on this paper prior to submission.

\section{Disclosure Statement}

There is no conflict of interest.

\section{Reference}

1 Stenmark KR, Abman SH: Lung vascular development: Implications for the pathogenesis of bronchopulmonary dysplasia. Annu Rev Physiol 2005;67:623-661.

2 Humbert M, Sitbon O, Simonneau G: Treatment of pulmonary arterial hypertension. N Engl J Med 2004;351:1425-1436.

3 Farber HW, Loscalzo J: Pulmonary arterial hypertension. N Engl J Med 2004;351:1655-1665.

4 Stenmark KR, Fagan KA, Frid MG: Hypoxia-induced pulmonary vascular remodeling: Cellular and molecular mechanisms. Circ Res 2006;99:675-691.

5 Kato M, Staub NC: Response of small pulmonary arteries to unilobar hypoxia and hypercapnia. Circ Res 1966;19:426-440.

6 Pak O, Aldashev A, Welsh D, Peacock A: The effects of hypoxia on the cells of the pulmonary vasculature. Eur Respir J 2007;30:364-372. 


\section{Cellular Physiology Cell Physiol Biochem 2015;35:2079-2097 \begin{tabular}{ll|l} 
and Biochemistry & $\begin{array}{l}\text { DOI: 10.1159/000374015 } \\
\text { Published online: April 07, } 2015\end{array}$ & $\begin{array}{l}\text { ○ 2015 S. Karger AG, Basel } \\
\text { www.karger.com/cpb }\end{array}$ \\
\hline
\end{tabular}}

Yu et al.: Role of MAPKs in Pulmonary Vascular Remodeling

7 Ma J, Liang S, Wang Z, Zhang L, Jiang J, Zheng J, Yu L, Zheng X, Wang R, Zhu D: Rock pathway participates in the processes that 15-hydroxyeicosatetraenoic acid (15-hete) mediated the pulmonary vascular remodeling induced by hypoxia in rat. J Cell Physiol 2010;222:82-94.

8 Owens GK, Kumar MS, Wamhoff BR: Molecular regulation of vascular smooth muscle cell differentiation in development and disease. Physiol Rev 2004;84:767-801.

9 Jin N, Hatton N, Swartz DR, Xia X, Harrington MA, Larsen SH, Rhoades RA: Hypoxia activates jun-n-terminal kinase, extracellular signal-regulated protein kinase, and p38 kinase in pulmonary arteries. Am J Respir Cell Mol Biol 2000;23:593-601.

10 Campbell JS, Seger R, Graves JD, Graves LM, Jensen AM, Krebs EG: The map kinase cascade. Recent Prog Horm Res 1995;50:131-159.

11 L'Allemain G: Deciphering the map kinase pathway. Prog Growth Factor Res 1994;5:291-334.

12 Duff JL, Berk BC, Corson MA: Angiotensin ii stimulates the pp44 and pp42 mitogen-activated protein kinases in cultured rat aortic smooth muscle cells. Biochem Biophys Res Commun 1992;188:257-264.

13 Koide M, Kawahara Y, Tsuda T, Ishida Y, Shii K, Yokoyama M: Endothelin-1 stimulates tyrosine phosphorylation and the activities of two mitogen-activated protein kinases in cultured vascular smooth muscle cells. J Hypertens 1992;10:1173-1182.

14 Molloy CJ, Taylor DS, Weber H: Angiotensin ii stimulation of rapid protein tyrosine phosphorylation and protein kinase activation in rat aortic smooth muscle cells. J Biol Chem 1993;268:7338-7345.

15 Abe J, Kusuhara M, Ulevitch RJ, Berk BC, Lee JD: Big mitogen-activated protein kinase 1 (bmk1) is a redoxsensitive kinase: J Biol Chem, 1996, 271, pp 16586-16590.

16 Han J, Lee JD, Bibbs L, Ulevitch RJ: A map kinase targeted by endotoxin and hyperosmolarity in mammalian cells. Science 1994;265:808-811.

17 Nick JA, Avdi NJ, Gerwins P, Johnson GL, Worthen GS: Activation of a p38 mitogen-activated protein kinase in human neutrophils by lipopolysaccharide. J Immunol 1996;156:4867-4875.

18 Ichijo H, Nishida E, Irie K, ten Dijke P, Saitoh M, Moriguchi T, Takagi M, Matsumoto K, Miyazono K, Gotoh Y: Induction of apoptosis by ask1, a mammalian mapkkk that activates sapk/jnk and p38 signaling pathways. Science 1997;275:90-94.

19 Coso OA, Teramoto H, Simonds WF, Gutkind JS: Signaling from g protein-coupled receptors to c-jun kinase involves beta gamma subunits of heterotrimeric g proteins acting on a ras and rac1-dependent pathway. J Biol Chem 1996;271:3963-3966.

20 Garcia NO, Pedraza RA: Daily rainfall variability over northeastern argentina in the la plata river basin. Ann N Y Acad Sci 2008;1146:303-319.

21 Woodgett JR, Avruch J, Kyriakis JM: Regulation of nuclear transcription factors by stress signals. Clin Exp Pharmacol Physiol 1995;22:281-283.

22 Modur V, Zimmerman GA, Prescott SM, McIntyre TM: Endothelial cell inflammatory responses to tumor necrosis factor alpha. Ceramide-dependent and -independent mitogen-activated protein kinase cascades. J Biol Chem 1996;271:13094-13102.

23 Natoli G, Costanzo A, Ianni A, Templeton DJ, Woodgett JR, Balsano C, Levrero M: Activation of sapk/jnk by tnf receptor 1 through a noncytotoxic traf2-dependent pathway. Science 1997;275:200-203.

24 Wei L, Liu Y, Kaneto H, Fanburg BL: Jnk regulates serotonin-mediated proliferation and migration of pulmonary artery smooth muscle cells. Am J Physiol Lung Cell Mol Physiol 2010;298:L863-869.

25 Zhang L, Li Y, Chen M, Su X, Yi D, Lu P, Zhu D: 15-lo/15-hete mediated vascular adventitia fibrosis via p38 mapk-dependent tgf-beta. J Cell Physiol 2014;229:245-257.

26 Dewachter L, Adnot S, Guignabert C, Tu L, Marcos E, Fadel E, Humbert M, Dartevelle P, Simonneau G, Naeije R, Eddahibi S: Bone morphogenetic protein signalling in heritable versus idiopathic pulmonary hypertension. Eur Respir J 2009;34:1100-1110.

27 Chen JD, Xu FF, Zhu H, Li XM, Tang B, Liu YL, Zhang Y: [icam-1 regulates differentiation of msc to adipocytes via activating mapk pathway]. Zhongguo Shi Yan Xue Ye Xue Za Zhi 2014;22:160-165.

28 Zhu D, Medhora M, Campbell WB, Spitzbarth N, Baker JE, Jacobs ER: Chronic hypoxia activates lung 15-lipoxygenase, which catalyzes production of 15-hete and enhances constriction in neonatal rabbit pulmonary arteries. Circ Res 2003;92:992-1000.

29 Ma C, Li Y, Ma J, Liu Y, Li Q, Niu S, Shen Z, Zhang L, Pan Z, Zhu D: Key role of 15-lipoxygenase/15hydroxyeicosatetraenoic acid in pulmonary vascular remodeling and vascular angiogenesis associated with hypoxic pulmonary hypertension. Hypertension 2011;58:679-688. 
30 Li J, Rao J, Liu Y, Cao Y, Zhang Y, Zhang Q, Zhu D: 15-lipoxygenase promotes chronic hypoxia-induced pulmonary artery inflammation via positive interaction with nuclear factor-kappab. Arterioscler Thromb Vasc Biol 2013;33:971-979.

31 Song Y, Jones JE, Beppu H, Keaney JF Jr, Loscalzo J, Zhang YY: Increased susceptibility to pulmonary hypertension in heterozygous bmpr2-mutant mice. Circulation 2005;112:553-562.

32 Wang Z, Tang X, Li Y, Leu C, Guo L, Zheng X, Zhu D: 20-hydroxyeicosatetraenoic acid inhibits the apoptotic responses in pulmonary artery smooth muscle cells. Eur J Pharmacol 2008;588:9-17.

33 Anwar A, Li M, Frid MG, Kumar B, Gerasimovskaya EV, Riddle SR, McKeon BA, Thukaram R, Meyrick BO, Fini MA, Stenmark KR: Osteopontin is an endogenous modulator of the constitutively activated phenotype of pulmonary adventitial fibroblasts in hypoxic pulmonary hypertension. Am J Physiol Lung Cell Mol Physiol 2012;303:L1-L11.

34 Li P, Oparil S, Feng W, Chen YF: Hypoxia-responsive growth factors upregulate periostin and osteopontin expression via distinct signaling pathways in rat pulmonary arterial smooth muscle cells. J Appl Physiol (1985) 2004;97:1550-1558; discussion 1549.

35 Paterlini P, Suberville AM, Zindy F, Melle J, Sonnier M, Marie JP, Dreyfus F, Brechot C: Cyclin a expression in human hematological malignancies: A new marker of cell proliferation. Cancer Res 1993;53:235-238.

36 Lagna G, Nguyen PH, Ni W, Hata A: Bmp-dependent activation of caspase-9 and caspase-8 mediates apoptosis in pulmonary artery smooth muscle cells. Am J Physiol Lung Cell Mol Physiol 2006;291:L10591067.

37 Han YH, Park WH: Treatment with p38 inhibitor partially prevents calu- 6 lung cancer cell death by a proteasome inhibitor, mg132. Cancer Genet Cytogenet 2010;199:81-88. 